\title{
Transcending Victimhood: Japan in the public historical museums of Taiwan and the People's Republic of China
}

\section{Edward Vickers}

\section{(2) OpenEdition Journals}

Electronic version

URL: http://journals.openedition.org/chinaperspectives/6316

DOI: 10.4000/chinaperspectives.6316

ISSN: 1996-4617

\section{Publisher}

Centre d'étude français sur la Chine contemporaine

\section{Printed version}

Date of publication: 1 December 2013

Number of pages: 3

ISSN: 2070-3449

\section{Electronic reference}

Edward Vickers, "Transcending Victimhood: Japan in the public historical museums of Taiwan and the People's Republic of China », China Perspectives [Online], 2013/4 | 2013, Online since 01 December 2016, connection on 28 October 2019. URL : http://journals.openedition.org/chinaperspectives/6316 ; DOI : 10.4000/chinaperspectives.6316 


\title{
Transcending Victimhood
}

\author{
Japan in the public historical museums of Taiwan and the People's Republic of China
}

\author{
EDWARD VICKERS
}

\begin{abstract}
This article looks at how the major national (or pseudo-national) historical museums in China and Taiwan interpret and display very different "new rememberings" of Japan. The main focus is on the permanent exhibitions of the modern history wing of the National Museum of China (NMC; formerly the Museum of the Chinese Revolution), which finally reopened in 2011 after almost a decade of refurbishment, and of the National Museum of Taiwan History (NMTH), which opened in the same year. It discusses how museum portrayals of Japan reflect divergent public discourses on national identity. Through examining the relationship between museums and the apparatus of the Chinese state (ROC and PRC), the first section locates the NMC and NMTH in their bureaucratic and political contexts. A typology of approaches to the construction of national identity is then offered, considering the implications of different conceptions of identity for portrayals of Japan and its relationship with China or Taiwan. The remainder of the article looks in turn at the NMC and NMTH, outlining the history of each before examining how Japan is represented in their permanent exhibitions. It concludes by considering what can be learnt from this about the evolving relationship between official historical discourse and the broader political context on both sides of the Taiwan Strait.
\end{abstract}

\section{KEYWORDS: China, Taiwan, museums, history, Japan, identity.}

$\mathrm{t}$ was in Meiji Japan that the language of nineteenth-century European nationalism was first given an East Asian inflexion, and thence that Chinese reformers derived some of their earliest blueprints for the apparatus of modern statehood. Among the Japanese institutions and practices that impressed them were museums, ${ }^{(1)}$ which, like their Western models, aspired to encompass the whole range of modern knowledge - from the natural sciences to geography, and from anthropology to "Art." History, conceived as a narrative of progress and nationalist teleology, was central to the structuring of this encyclopaedic enterprise, and to the broader project of fostering a sense of modern citizenship. Whereas traditional historiography addressed itself to the moral formation of the civilised man and loyal official, the rigours of a world of nations locked in eternal Darwinian struggle seemed to demand a new narrative and a new morality. Confronted by "the challenges of an era in which the quest for national strength became the primary intellectual aim," modernisers rallied to the 1902 call of Liang Qichao (one of many who studied in Japan) for a "New History" that would place "the people" centre stage, forging a cohesive sense of national identity. (2) This was to be among the chief tasks assigned to the institutions of the modern Chinese state whether Nationalist (Kuomintang) or Communist.

Over the past century, other models and other ethical frameworks have impinged on China's museums. In the People's Republic (PRC), for example, Soviet precedents have left a deep institutional imprint, even while classbased definitions of "the people" have fallen from favour. Nonetheless, through their various ideological shifts, the regimes facing off across the Taiwan Strait have continued to see the production and dissemination of authoritative narratives of the national past as a crucial task of the state. Museums of national history constitute a key public manifestation of these authorised visions.

Despite, or perhaps because of, the immense Japanese impact on modern China, for most of the twentieth century Japan did not feature prominently in these official historical narratives. It is only since the 1980s that the war with Japan has been subject to a "new remembering" within the PRC, as historical scholarship has enjoyed broader licence, and as political considerations - the need for a new legitimating strategy, hopes for reunification with Taiwan - have encouraged greater emphasis on the role of all China's people, including the Kuomintang (KMT), in a united "patriotic" struggle. ${ }^{(3)}$ "Ironically," Parks Coble remarks, "this appeal to the Kuomintang occurred just as the party began to lose its grip on the island." (4) This political transition was accompanied by a "new remembering" of Taiwan's own past as a Japanese colony. While the KMT celebrated its own victory over Japan, lambasting the treachery of the Communist Party (CCP) (which fully repaid the compliment), official accounts devoted little attention to Taiwan itself, or to Japan's place in its history, except to underline the essential "Chineseness" of the island and its people. ${ }^{(5)}$ With the arrival of democratisation and "localisation" (bentuhua) from the late 1980s onwards, this changed drastically. For many repelled by the prospect of reunification, embracing Taiwan's

1. See Qin Shao, "Exhibiting the Modern: The Creation of the First Chinese Museum, 1905-1930," The China Quarterly, Vol. 179, September 2004, pp. 684-702, documenting the history of the Nantong Museum in Jiangsu Province. Shao emphasises the origins of the institution of the museum in "Western modernity" rather than the ways in which "modernity" was, for the museum's founder and many of his contemporaries, refracted through a Japanese lens. By contrast, Refracted Modernity, edited by Yuko Kikuchi (University of Hawai'i Press, 2005), emphasizes precisely this process, looking at the cultural impact of Japan on Taiwanese society during the colonial period.

2. Luo Zhitian, "The Marginalisation of Classical Studies and the Rising Prominence of Historical Studies during the Late Qing and Early Republic: A Reappraisal," in Brian Moloughney and Peter Zarrow (ed), Transforming History: the Making of a Modern Academic Discipline in 20th-century China, Hong Kong, The Chinese University Press, 2011, pp. 47-74, pp. 60-61.

3. Parks M. Coble, "China's 'New Remembering' of the Anti-Japanese War of Resistance, 1937-1945," The China Quarterly, Vol. 190, 2007, pp. 394-410.

4. Ibid., p. 402

5. Alisa Jones, "Triangulating Identity: Japan's Place in Taiwan's Textbooks," in Paul Morris, Naoko Shimazu, and Edward Vickers (eds), Imagining Japan in Postwar East Asia, Routledge, forthcoming 2013. 
Japanese heritage became one way of asserting a "multicultural" identity distinct from the monolithic "China" of both KMT and CCP imaginings.

This article looks at how the major national (or pseudo-national) historical museums in China and Taiwan interpret and display these very different "new rememberings" of Japan. The main focus is on the permanent exhibitions of the modern history wing of the National Museum of China (formerly the Museum of the Chinese Revolution) (NMC), which finally reopened in 2011 after almost a decade of refurbishment, and of the $\mathrm{Na}$ tional Museum of Taiwan History (NMTH), which opened in the same year. It discusses how museum portrayals of Japan reflect the divergent public discourse on national identity on either side of the Taiwan Strait. At the same time, it analyses what the contrasting presentational mode of each exhibition - the way in which images of Japan are conveyed to the visitor - suggest about change (or the lack of it) in official conceptions of the social and political role of the museum.

Through examining the relationship between museums and the apparatus of the Chinese state (ROC and PRC), the first section locates the NMC and NMTH in their bureaucratic and political contexts. The next section discusses the various forms of identity that museums have been used to convey, how and why emphasis has shifted, and what this has meant for the depiction of Japan - citing examples from other institutions and other media, official (e.g. school textbooks) and non-official. The remainder of the article looks in turn at the NMC and NMTH, outlining the history of each before examining how Japan is represented in their permanent exhibitions. It concludes by considering what can be learnt from this about the evolving relationship between state and people, and between official historical discourse and the broader political context, in China and Taiwan.

\section{Chinese and Taiwanese museums in political context}

Museums can take various forms - from imposing architectural monuments to "universal" human endeavour, to embodiments of national or civic pride, to the more modest products of communal or private initiative. They can likewise serve a variety of functions: commemorating the philanthropic collector or great leader, reconstructing the everyday life of our ancestors, imparting "civilisation" to the masses, inculcating ideological "correctness" or patriotic enthusiasm, promoting dissenting narratives, introducing the wonders of high art or modern science, or displaying vernacular arts and crafts. Besides their educative or recreational functions, many also serve as important centres for conservation or research. "In contemporary museum display," according to one specialist, "there is an on-going conflict between the construction of meanings that support an authorised collective memory, frequently linked to a linear narrative of progress, and an ambition to act as places of pluralism and inclusion." (6)

The rapidly expanding museums scene in both mainland China and Taiwan reflects this variety and tension - though more so in post-Martial Law Taiwan than in post-Tiananmen China. Lavishly-funded new projects feature slick displays incorporating the latest technological gimmickry, even when conventionally didactic conceptions of the museum's role persist. In addition, a veritable fever of state-sponsored museum-building, renovation, and expansion has been fuelled, in Taiwan as in China, by competition between cities and regions for prestige and the increasingly significant tourist dollar or yuan. The national historical museums examined here therefore cannot be taken as representative even of public museums - but they do occupy a highly symbolic position within the public cultural "space" of their respective states.

That space itself has been largely defined by a hierarchy of public cultural institutions. The role of museums in arousing a sense of national pride has received particular emphasis in mainland China since the 1990s, as the language of universal class struggle has been abandoned in favour of a more explicitly nationalist narrative. However, underlying the ideological twists and turns of the past 80 years or more has been a consistent emphasis by both KMT and CCP regimes - on the use of museums for inculcating a homogenous and totalising sense of "Chineseness." The iconic Western museums - such as the Louvre, the British Museum, or New York's Metropolitan Museum - have aspired to present a vision of universal human civilisation (even when this simultaneously involved national aggrandisement). By contrast, China's museums have reflected a retreat from the universalist claims of traditional thought to a narrower focus on defining the nation. They have typically asserted China's essential difference from, and victimisation by, the "imperialist" powers, as well as the eventually triumphant national struggle to assert parity with the latter. ${ }^{(7)}$ The Leninist origins of both KMT and CCP, combined with deeply-rooted assumptions concerning the "pedagogic" relationship between rulers and ruled, ${ }^{(8)}$ implied a strong focus on enforcing ideological conformity. Museums have been subjected to close oversight by ministries of Culture, Propaganda, or Education, and - in the case of key national institutions - to that of senior party leaders themselves. ${ }^{(9)}$

Democratic Taiwan has essentially retained a cultural bureaucracy inherited from the Republic of China ( $R O C$ ) as constituted on the mainland during the 1930s. "National" museums falling under the control of the Ministry of Education include a "National Museum of History" (NMH) (not to be confused with the NMTH) founded to promote Taiwanese appreciation of and identification with "Chinese" civilisation. So too was the supreme symbol of the ROC state's claim to custodianship of China's heritage, the National Palace Museum (NPM), whose director to this day enjoys the rank of cabinet minister. The NMTH comes under the authority of the "Council for Cultural Affairs," originally an organ of the "Taiwan Provincial Government" that operated in parallel with the "national" ROC government until the late 1990s. Since the abolition of the provincial tier, the CCA answers directly to the national cabinet, the "Executive Yuan." Since the 1980s, Taiwan has also witnessed a surge in the number of museums established by private foundations or local authorities, most of them - notably the Shun Ye Museum of Taiwan Aborigines and the Shisanhang Museum near Taipei - devoted to the conservation and display of distinctively Taiwanese artefacts. ${ }^{(10)}$

The PRC has also maintained the national/provincial hierarchy established during the Republican period, with "national" museums (e.g. the NPM and $\mathrm{NMC}$ ) answering to the central government, and provincial museums oc-

6. Dr Graham Black, review of Museums and Biographies: Stories, Objects, Identities, (review No. 1399), www.history.ac.uk/reviews/review/1399 (accessed on 21 March 2013).

7. Qin Shao, "Exhibiting the Modern," op. cit., notes how the international and racial hierarchy posited by Western expositions and museums contributed to "anxiety among the disadvantaged countries to prove themselves" (687). A similar point is made - with reference to Japan - by Shao-li Lu in Zhanshi Taiwan: quanli, kongjian yu zhimin tongzhi de xingxiang biaoshu (Exhibiting Taiwan: Power, space and image representation of Japanese colonial rule), Taipei, Maitian, Rye Field Publications, 2005.

8. John Fitzgerald, Awakening China: Politics, Culture and Class in the Nationalist Revolution, Stanford University Press, 1996.

9. Chang-tai Hung, "The Red Line: Creating a Museum of the Chinese Revolution," in The China Quarterly, Vol. 184, December 2005, p. 924.

10. See Edward Vickers, "History, Identity, and the Politics of Taiwan's Museums: Reflections on the DPP-KMT Transition," China Perspectives, No. 2010/3, pp. 92-106. 
cupying a lower tier in the hierarchy. In the PRC, as in the ROC of the 1920s1940s, it remains the case that "the universe of the provincial museum is the nation"; ${ }^{(11)}$ the provincial museum's principal mission is to show how local history and archaeology conform to a teleological narrative of the unification and assimilation of the Chinese race-nation (Zhonghua minzu). ${ }^{(12)}$ The propaganda organs of state and party closely supervise all exhibitions for ideological correctness, and since the early 1990s museums have played an important role in the "patriotic education campaign" launched after the suppression of the 1989 Student Movement. As in the former Soviet Union, particular ministries also have their own museums: thus the Defence Ministry controls the "Military Museum of the Chinese People's Revolution," while the "China Space Museum" falls under the authority of the China National Space Administration. "Memorial halls" and former residences of various famous figures also constitute a significant category of museums in the PRC, as they did in the former USSR. ${ }^{(13)}$ Lastly, China has in recent years witnessed the establishment of a small number of private museums - but these cannot survive without the constant and assiduous cultivation of "connections" with local officialdom, compelling them, in essential respects, to toe the orthodox historical line.

Public museums in both the ROC and PRC thus mediate official discourses on national history and identity - but what is the nature of these discourses, how have they changed in recent years, and how consistent or coherent are they? Although space does not permit an exhaustive discussion, it will be useful to outline some of the key ways in which identity is conceptualised, and how these relate to portrayals of the historical relationship between Japan and China.

Biology or race has been a key category of identity for modern Chinese nationalists, melding a deeply-embedded familistic concern with blood lines with the pseudo-science of Darwinian racialism. Biological conceptions of Chinese nationhood took root in the early twentieth century and Republican periods, when the National Central Museum "embraced ethnology (with a particular emphasis on the study of border peoples) and biological evolution with the aim of demonstrating that human life originated in China." (14) Race-based notions of identity have been reflected in the practice - common to the ROC and PRC - of beginning textbook narratives of Chinese history with discussions of Peking Man. The museum at Zhoukoudian, just outside Beijing, commemorating the discovery of Peking Man, stresses the common racial origins of all East Asians, while also recording how looting by Japanese troops during the War of Resistance led to the loss of the most complete set of Peking Man remains. Thus biology invokes a common East Asian heritage, while also reminding Chinese of how that shared legacy has been despoiled by Japan - the black sheep of the "Mongoloid" family. Meanwhile, on Taiwan, a recent trend towards emphasising the intermingling, over several centuries, of the island's Chinese immigrant population with Austronesian indigenes has been related to attempts to establish a biological case for Taiwanese nationhood, asserting a genetic divide with the putative "motherland" across the water.

Cultural notions of identity likewise serve both to unite and divide. Official encouragement within the PRC of the growing fashion for Confucianism is attested by recent changes to the school curriculum, ${ }^{(15)}$ the naming of the "institutes" established to promote China's language and culture internationally, and the erection of numerous statues of Confucius - including one outside the NMC in Beijing. In his hometown of Qufu, the Confucius Research Institute (established in the early 2000s) celebrates the characteristic "Confucian" virtues, including filial piety and an emphasis on societal "har- mony," while highlighting the East Asian scope of a Confucian cultural sphere. However, this vogue for the sage's teachings, invoking notions of cultural identity long promoted by the KMT on Taiwan, has been controversial within the PRC - with both liberals and leftists objecting to a philosophy associated with such "pre-liberation" practices as discrimination against women and class oppression. Moreover, on Taiwan, the singular association of cultural identity with a conservative, traditionalist notion of Chineseness has increasingly been challenged. In Tainan, the southern city also home to the NMTH, the National Museum of Taiwan Literature (established in 2003), housed in a renovated Japanese colonial building, emphasises the diverse roots of modern Taiwan's literary heritage. Here as elsewhere, tracing the Japanese provenance of certain ingredients helps to dilute the "Chinese" flavour of Taiwan's cultural recipe.

Symbols of national identity - iconic monuments or heroic individuals can also embody complex and contradictory messages. Thus the Ming loyalist Zheng Chenggong, autonomous ruler of Taiwan in the mid-seventeenth century, has been celebrated by both KMT and CCP regimes as a "national hero" (for expelling Dutch colonialists), but also hailed by separatists as a symbol of Taiwanese "multiculturalism" (his mother was Japanese). ${ }^{(16)}$ The Great Wall, built with the aim of keeping the Mongol hordes out of China Proper, has been reinterpreted in museums (for example at Badaling near Beijing) and in orthodox PRC historiography as a symbol of the "multicultural" origins of the Chinese nation, while the greatest of the Mongol invaders, Genghis Khan himself, has been recast as a Chinese national hero. Efforts to appropriate the Chinggisid conquests as part of China's glorious heritage would appear to encompass Yuan Dynasty Emperor Khubilai Khan's (failed) attempts to invade Japan in 1274 and 1281 - though this implication is entertained nowhere in museums or official historical texts.

If culture, biology, and myth supply visions of identity in which Japan occupies an ambivalent position, so does the history of the modern nationbuilding project itself. Japan provided early templates for the establishment of institutions (including schools, universities, and museums) tasked with socialising the masses as citizens of a modern nation. In addition, Japanese colonial rule in Taiwan, Korea, and Manchuria was strongly "developmentalist" in that it sought not only to extract resources and dominate local markets, but also to integrate these territories - their agriculture, industry, and commerce, as well as their culture, language, and administration - with the imperial metropolis. ${ }^{177)}$ Hence the post-war industrialisation of China's North East built upon foundations bequeathed by Japanese industrialists and administrators (including Kishi Nobusuke, the grandfather of Japan's current Prime Minister, Abe Shinzo). Memories of invasion and oppression,

11. John Fitzgerald, Awakening China: Politics, Culture and Class in the Nationalist Revolution, op. cit., p. 53.

12. Although there are considerable differences in the emphasis of the museum exhibitions in different provinces or regions: Shanghai's more cosmopolitan, Beijing's more stridently anti-imperialist, those of "minority" regions more imbued with "socialist" perspectives and evincing less Han chauvinism.

13. Chang-tai Hung, "The Red Line: Creating a Museum of the Chinese Revolution," art. cit.

14. John Fitzgerald, Awakening China: Politics, Culture and Class in the Nationalist Revolution, op. cit., p. 54.

15. Wencheng Zhu, Confucian Themes and China's High School Language and Literature Textbooks in the Reform Era, unpublished PhD thesis, Institute of Education, University of London, 2012.

16. See Edward Vickers, "History, Identity, and the Politics of Taiwan's Museums: Reflections on the DPP-KMT Transition," art. cit.

17. Prasenjit Duara, Sovereignty and Authenticity: Manchukuo and the East Asian Modern, Rowman and Littlefield, 2003. See also Andrew Hall, "The Word is Mightier than the Throne: Bucking Colonial Education Trends in Manchukuo," in The Journal of Asian Studies, Vol. 68, No. 3, August 2009, pp. 895-925 
and the political imperative of insisting on the autochthonous origins of modernisation, have fuelled reluctance to acknowledge any constructive dimension to Japan's impact on national development. The post-Tiananmen CCP, like the KMT under the two Chiangs, has presented China's modern history as a long struggle against foreign oppression, even if the identity of the chief oppressors has shifted with contemporary political exigency. In post-Martial Law Taiwan, by contrast, open controversy over how to evaluate the contributions of Qing, Japanese, and Chinese Nationalist rulers to local development has reflected contemporary argument over the island's identity and destiny.

Finally, a dimension of identity with particular relevance to portrayals and perceptions of Japan is that of national victimhood. As Paul Cohen demonstrates, stories dwelling on the experience of humiliation were amongst those most avidly reproduced, read, and performed in twentieth-century China. ${ }^{(18)}$ In addition, a national self-image of aggrieved innocence is assisted by the occlusion of past instances in which the jackboot of oppression clad the Chinese foot. In mainland China since the 1980s, and especially since the post-Tiananmen launching of the Patriotic Education Campaign, monuments to Japanese iniquity have sprouted across the landscape; ${ }^{(19)}$ the fate of ethnic minorities subjected to Chinese rule, and the victims of Mao's disastrous campaigns, meanwhile go un-commemorated. But in Taiwan, too, a concern to underline the victimhood of ethnically Han Taiwanese has often obscured the role of their ancestors in displacing the indigenous inhabitants. ${ }^{(20)}$ While, since the early 1990s, more and more museums have celebrated the cultures of indigenous Polynesian tribes, few have devoted much attention to the fraught history of interaction between the latter and Chinese settlers who colonised the island from the seventeenth century. ${ }^{(21)}$

Contemporary Taiwanese and Chinese identity discourse, as reflected in museums, thus exhibits many similarities - unsurprisingly, in view of the profound linguistic and cultural commonalities shared across the divide. However, while both sides draw on a common stock of concepts and referents, these have come to be deployed to very different effect. This will become apparent in the analysis of the NMC and NMTH permanent exhibitions. These represent the most recent and ambitious officially-sponsored efforts to enshrine a public narrative of the modern history of, respectively, China and Taiwan. As such, both represent the outcome of attempts, spanning two decades, to redefine the relationship between state and nation in the aftermath of wrenching political and social transformation. The very different nature of that transformation in each case is in turn reflected in the status of the museum exhibition itself - in the extent to which it embodies an evolving consensus regarding the collective past, or seeks to impose a new ideological orthodoxy on "the masses." Given Japan's centrality to debates over recent history on both sides of the Taiwan Strait, its portrayal offers an excellent window onto this process.

\section{Japan in the National Museum of China}

The NMC is an amalgamation of the two museums that previously shared the building flanking the eastern side of Tiananmen Square: the Museum of the Chinese Revolution (MCR) and the Museum of Chinese History. ${ }^{(22)}$ The focus here is on the "modern" section of the museum, based on the former MCR and occupying the same (north) wing of the building. The purpose of the MCR has been described as "to legitimize the CCP's rule by carefully recreating, through exhibitions, a desirable image of the Party with which to impress the public, and to highlight the pivotal role played by Mao Ze- dong (1893-1976) in guiding the Party to its final victory." (23) A leading figure in the creation of the MCR, the Communist intellectual Wang Yeqiu, sought to differentiate it from museums founded by "foreign imperialists" (for example in treaty ports such as Shanghai), or the "antique display cases" established by Chinese themselves (perhaps having in mind the nearby $\mathrm{Na}$ tional Palace Museum). Travelling to the USSR in 1950, he visited the National Museum of the Revolution, noting the prominence given to Lenin and Stalin, and the periodisation of revolutionary history into four stages, the last dealing with the construction of socialism. He enthusiastically endorsed the way that Soviet museums were "inextricably linked with the people, serving as their classroom" (24) - echoing Jacques-Louis David's vision of the Louvre as an "imposing school." (25) Among the aspects of the MCR that most closely followed Soviet precedent (in turn influenced by the work of David (26)) was the commissioning of grand paintings celebrating the achievements of the Revolution and of heroic individuals. As we shall see, these continue to feature prominently in the NMC's modern history exhibition.

The MCR exhibition was organised on the basis of the periodisation of modern Chinese history proposed in Mao Zedong's 1940 essay, On New Democracy. ${ }^{(27)}$ Originally, it was to have consisted of three main sections: the "Old Democratic Revolution" (1840-1919), beginning with the Opium War; the "New Democratic Revolution" (1919-1949), taking the story from the May $4^{\text {th }}$ Movement and founding of the CCP to the eventual Communist triumph in 1949; and finally a section on the post-1949 "socialist Period" itself. However, the latter section was ultimately dropped from the plans, so that when the museum opened in 1961, its historical narrative ended in 1949. Hung explains that the CCP Central Committee (senior members of which, including Premier Zhou Enlai, closely scrutinised the project) took the view that the section on the "New Democratic Revolution" was "difficult" enough - for ideological reasons, and because many of the actors were still living; portraying events post- 1949 would have led museum staff into a veritable political minefield. (28) Indeed, it was not until its twenty-firstcentury refurbishment that substantial coverage of the post-1949 period was finally added - many of the principal actors having by then long been safely consigned to their graves.

18. Paul Cohen, Speaking to History: The story of King Goujian in Twentieth-century China, Berkeley, University of California Press, 2010.

19. Museums and memorials relating to Japanese aggression and oppression include the Crime Evidence Exhibition Hall of Japanese Imperial Army Unit 731 (notorious for testing chemical and biological weapons on live human subjects) near Harbin; the September 18 History Museum in Shenyang (commemorating the "Mukden Incident" of 1931); the Lugouqiao Memorial Hall to the People's War of Resistance against Japan (near the "Marco Polo Bridge" south of Beijing); and the Nanjing Massacre Memorial. See Kirk Denton, "Heroic Resistance and Victims of Atrocity: Negotiating the Memory of Japanese Imperialism in Chinese Museums," Japan Focus, No. 2547, October 2007.

20. Edward Vickers, "Original Sin on the Island Paradise: Qing Taiwan's Colonial History in Comparative Perspective," Taiwan in Comparative Perspective, Vol. 2, 2008, pp. 65-86.

21. Edward Vickers, "Rewriting Museums in Taiwan," in Fang-long Shih, Stuart Thompson, and PaulFrancois Tremlett (eds), Rewriting Culture in Taiwan, London, Routledge, 2009, pp. 69-101.

22. Building began in 1958, as part of a project to celebrate the tenth anniversary of the founding of the PRC. See Chang-tai Hung, "The Red Line: Creating a Museum of the Chinese Revolution," art. cit.

23. Ibid., p. 915 .

24. Ibid., p. 918

25. Ibid., p. 919.

26. Although David's work was already known in China before 1949. See Kirk Denton, "Visual Memory and the Construction of a Revolutionary Past: Paintings from the Museum of the Chinese Revolution," in Modern Chinese Literature and Culture, Vol. 12, No. 2, Fall 2000, p. 206.

27. Chang-tai Hung, "The Red Line: Creating a Museum of the Chinese Revolution," art. cit., p. 927.

28. Ibid., p. 928 
Refurbishment began in 2003, with reopening originally scheduled for 2007, in time for the Beijing Olympics, but delayed due to debates over the choice of design for the permanent exhibition and changes in museum leadership. ${ }^{(29)}$ Along with the Great Hall of the People that faces it, the NMC building was originally designed to flank a huge space for mass rallies, themselves signifying the "revolutionary" character of the Communist regime. The creation of a merged NMC, with the dropping of the word "revolution" from the museum's title, coincided with a remodelling of Tiananmen Square itself. Since 1989, mass gatherings on the square have become extremely rare, ${ }^{(30)}$ and new structures have been erected, celebrating the achievements of the regime while also breaking up the space and making it easier to police. Huge walls, adorned with digital screens displaying slogans and propaganda videos, now bisect the square along its East-West axis. Meanwhile, in front of the NMC itself just prior to its reopening, a statue of Confucius was unveiled - prompting uproar amongst those who objected to the sage's association with "feudal" thought, or to the hypocrisy of seeking to associate the CCP with a figure whose vilification during the Maoist era had yet to be officially renounced. (31) The statue was subsequently relocated to a less prominent spot within the museum precincts, but its erection nonetheless constituted further evidence of a desire to associate the museum, and the space surrounding it, with symbols of the regime's custodianship of China's heritage, rather than with any transformative revolutionary vision.

The renunciation of "revolution" is evident from the very outset in the NMC's new modern history section, rechristened "the road to rejuvenation" (fuxing zhi lu). In place of the huge bust of Chairman Mao that had originally graced the entrance hall of the MCR, ${ }^{(32)}$ visitors are greeted by murals celebrating China's technological prowess and global status. Rather than constituting a drastic break with the past, the nation's modern history is thus represented as a quest to restore the glories of an ancient civilisation (on display in the NMC's southern wing) and to recover its rightful place in the world. Although occasional references are made to the struggle of "the masses" against the "feudal ruling classes," popular uprisings such as the Taiping Rebellion or the Boxer Rising feature only fleetingly - a significant contrast with the old MCR. Rather than being structured around the two "revolutionary" periods ("Old Democratic" and "New Democratic"), the new exhibition takes as its main theme the struggle of the Chinese people (including "feudal" and "bourgeois" elements) against foreign depredation, and their efforts, especially under Communist leadership, to build a strong, modern nation.

Part One of the exhibition, entitled "China is reduced to a semi-colonial and semi-feudal condition," deals with the "imperialist" onslaught of the nineteenth century. Imperialism is portrayed as an originally European phenomenon, and prominence is accorded to the iniquities of the opium trade and the associated war - commemorated in a new diorama depicting Chinese troops valiantly fending off the British. Sufferings inflicted by the imperialists - ranging from discrimination in the treaty ports to exploitative and degrading working conditions in foreign-owned industries - are depicted in numerous old photos, as well as a newly-commissioned statue entitled "The Chinese people mired in misery" (Ku nan de Zhongguo renmin). (33) The idea that domestic factors may have contributed to this "misery" is hardly entertained. On the other hand, Japan's role in inflicting suffering is highlighted with the addition of a large new oil painting depicting an incident during the Sino-Japanese war of 1894-95, the "Lushun Massacre": beneath the rising sun flag, Japanese soldiers are shown brutally hacking down Chinese civilians; a corpse with severed head lies in the fore- ground, while at the centre of the painting an elderly woman, a mother, and a small child cower at the point of a bayonet. ${ }^{(34)}$ The style - very much in the Soviet-inflected tradition of revolutionary art - is identical to that of a 1961 painting showing the "Sino-Japanese battle of the Yellow Sea." (35) However, whereas the latter depicts two modern warships firing at each other, with human figures barely visible, in the 2009 work the villainy of the Japanese figures and the suffering of their defenceless Chinese victims is very much to the fore.

Having emphasised the nation's dire plight in the opening section, "Part Two" depicts Chinese people "Looking for a way to save the nation." Facing continuing foreign oppression, as well as popular discontent (the Taiping Rebellion is briefly covered), the country's "feudal rulers" are portrayed as making belated and inadequate attempts at reform - notably in the "Late Qing Reforms" of the first decade of the twentieth century. ${ }^{\left({ }^{36}\right)}$ This period featured massive policy borrowing from Japan, but although one picture shows officials being sent on a study tour to America, the Japanese influence on reformist thinking is not acknowledged. ${ }^{(37)}$ A panel reproducing the founding declaration of the Tongmenghui (a revolutionary society established by Sun Yat-sen) notes that this event took place in Japan, but the broader influence of Japanese thought and practice, and the country's status as a haven for Chinese reformists and radicals, are not discussed. Significant space is devoted to accounts of heroic efforts to overthrow the "feudal" imperial regime, culminating in the 1911 Revolution - but this is represented as a failed "bourgeois" enterprise that "did not change the nature of Chinese society." In cataloguing the failures of the post-1911 regime, Japan once more enters the frame - as the author of the notorious "Twenty-one demands" of 1915 that sought the cession of large chunks of Chinese territory and sovereignty. ${ }^{(38)}$ Although full implementation of this agreement was blocked by the Western powers, the exhibition highlights how the decision at Versailles in 1919 to transfer to Japan Germany's privileges in Shandong sparked off the May 4th Movement. This in turn formed the backdrop to the "earthshattering event" of the CCP's foundation.

Like the old MCR, the modern history wing of the NMC takes as its fundamental mission the highlighting of the essential role of the CCP in achieving national salvation. "Part Three" thus aims to demonstrate the Party's

29. Senior party leaders have historically taken a close interest in the presentation of history in the NMC/MCR, though details are hard to pin down. Chang-tai Hung notes that, as of 2005, the archives of the museum "remain closed to outsiders," (Chang-tai Hung, "The Red Line," art. cit., p. 929).

30. And invariably carefully drilled and stage-managed.

31. See "Controversial Confucius statue vanishes from Tiananmen," www.reuters.com/ article/2011/04/22/us-china-conficius-idUSTRE73LOY420110422 (accessed 26 March 2013).

32. This was how the exhibition opened in the 1960s, according to Chang-tai Hung (Chang-tai Hung, "The Red Line," art. cit.), but - if the present author's memory serves - the bust of Mao no longer greeted visitors to the MCR in the 1990s.

33. By Li Xiangqun, 2009.

34. "The Lushun Massacre," by Li Wu and Li Fulai, 2009.

35. Wu Shuyang, 1961.

36. Here some of the old Marxist terminology is deployed in section titles: for example, with references to "the Landlord Class," and "the Capitalist Reformists" - but the theme of class struggle is otherwise largely ignored in the actual exhibition text. The term "feudal" is frequently deployed, but is nowhere defined.

37. Liang Qichao features in this section, with panels quoting from his works - but the influence of Japan on his educational and constitutional thought is ignored.

38. Controversy has recently arisen regarding Sun Yat-sen's relationship with Japan, since there is evidence that he may have been willing to accept the 21 demands in return for Japanese support for his efforts to overthrow Yuan Shikai. See Yang Kuisong, "Was Sun Yat-sen patriotic or not?", (Sun Zhongshan daodi ai bu ai guo?), Dongfang lishi pinglun, 15 July 2013, http://history.sina .com.cn/his/bk/2013-07-15/164950399.shtml (accessed on July 30 2013). Sun's very close ties to Japan are nowhere acknowledged or discussed in this exhibition. 


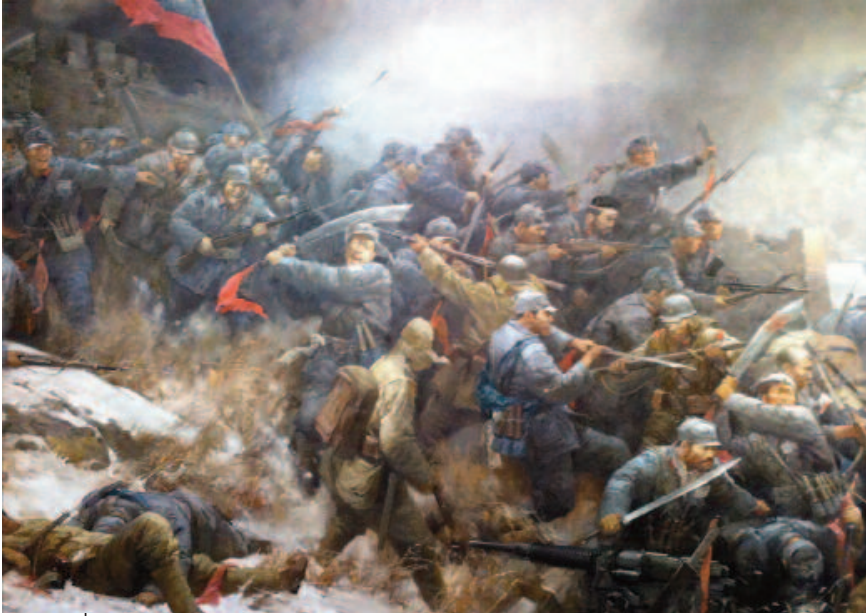

Photo 1 - Detail from "Cut the Devil's Head with a Broadsword" by Yan Yang and Li Fulai (2009). (Photograph by the author)

assumption of "the historic burden of making the country independent and liberating its people." In common with other Chinese museums (and school textbooks) since the 1990s, the narrative takes a more indulgent view of the efforts by "other strata of Chinese society" to "put forward ideas for how to save the nation" - but insists these "were not a solution to China's fundamental problems." Chiang Kai-shek and "KMT Rightists" (though not the KMT as a whole) are condemned for "betraying the revolution," but the question of precisely which "fundamental problems" they and "other strata" failed to tackle is not clearly addressed. ${ }^{(39)}$ Considerable space is devoted to displaying photographs and artefacts related to the CCP's struggles of the late 1920s and early 1930s, the Long March of 1934-36, and the establishment of the CCP base in Yan'an. However, while photographs and potted biographies of various key leaders and foreign supporters are provided, there is no discussion of the radically egalitarian social policies piloted in Yan'an, or of the ideological controversies that punctuated the CCP's sojourn there. The existence, let alone the identity, of domestic "class enemies" is barely mentioned in this account; instead, the story of the CCP's survival serves merely as a prelude to the climactic struggle against an external foe: Japan.

The old MCR devoted its hall on the "War of Resistance" overwhelmingly to coverage of the CCP contribution (and that of Chairman Mao in particular) to the war against Japan but, according to Hung, did not really highlight the issue of Japanese aggression or atrocities. The new exhibition describes the Party as "the tower of strength in the people's War of Resistance Against Japanese Aggression" (quan minzu kangzhan de zhongliu dizhu), and likewise devotes the most space to photographs and artefacts relating to the CCP struggle (including many images of Mao). However, the section on the War begins with an assertion that, following World War One, Japan "intensified efforts to implement the policy of invading China" (implying that this was already confirmed Japanese policy). A photograph is shown of Prime Minister Tanaka Giichi convening the Far Eastern Conference in 1927, but no mention is made of the controversy amongst historians concerning the veracity of the "Tanaka Memorial" in which this invasion policy was supposedly enshrined. The photograph immediately below shows the Mukden (Shenyang) incident of 18 September 1931, thus reinforcing the impression that the invasion of Manchuria, and later of China as a whole, was the outcome of a coolly calculated Japanese plot. No information concerning domestic developments in Japan during the 1920s and 1930s is supplied, and the dis-

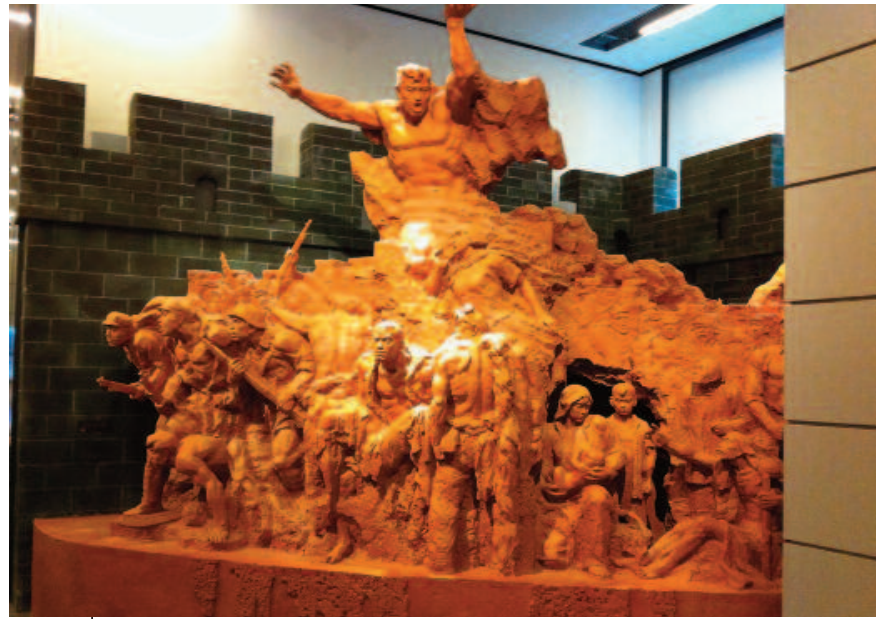

Photo 2 - The installation "Flesh and Blood Great Wall" by Ye Yunshan (2009), in the NMC gallery. (Photograph by the author)

tinction traditionally drawn in CCP propaganda between a militarist ruling clique and the put-upon Japanese "masses" is absent. Grisly photographs of atrocities in Nanjing (giving a figure of 300,000 killed) and elsewhere appear calculated to arouse righteous indignation against Japanese barbarism.

Patriotic anti-Japanese sentiment is represented in three new artworks commissioned for this section of the exhibition. Dominating the space is a socialist-realist sculpture entitled "Flesh and Blood Great Wall" (Xue rou chang cheng). ${ }^{(40)}$ This shows grimly-determined figures emerging out of solid rock, the ensemble topped by a monumental male figure, arms raised, ushering his compatriots to advance on the unseen Japanese enemy. Adjacent to this is a new painting, "Cut the Devil's Head with a Broadsword" (Da dao xiang guizimen de tou shang gequ). ${ }^{(41)}$ What is also notable about this painting is that the heroic Chinese figures are soldiers in the Kuomintang army, carrying into battle the KMT flag. While the NMC does not go as far as some other recently-established or renovated museums in rehabilitating the KMT and Chiang Kai-shek, ${ }^{(42)}$ these additions to the display serve to underline the unified nature of Chinese resistance. Similarly, a 2003 painting entitled "9 a.m., 9 September 1945" (Gongyuan yiqian jiubai sishiwu nian jiu yue jiu ri jiu shi) shows Japanese generals bowing in submission as they present the surrender document to impassive Chinese representatives before an audience of Chinese people and soldiers, in a monumental hall decked with the flags of the Allied powers (China once again represented by the KMT flag). This painting, displayed above cases of captured Japanese weapons, shows Chinese greeting their victory with calm dignity. Moreover, the victory is represented very much as a Chinese achievement, notwithstanding passing references in the exhibition to the involvement of other Allied powers, and to the American bombings of Hiroshima and Nagasaki.

39. A painting by Yin Rongsheng, dated 1975 (i.e. during the Cultural Revolution), shows happy peasants "Burning Land Deeds," but the significance of this act and its relationship to the theme of "class struggle" is not discussed.

40. Ye Yushan, 2009. The title is a quotation from the Chinese national anthem. A similar bronze relief, with the same title, graces the atrium of the War of Resistance Memorial Hall at Lugouqiao outside Beijing. (I am grateful to an anonymous reviewer for providing the latter information).

41. Yan Yang and Li Fulai, 2009. The use of the term guizi ("devil" or "demon") to refer to Japanese soldiers is common in the Chinese media and in school texts, although at odds with the CCP's supposed insistence on distinguishing between Japan's malevolent wartime leadership and the ordinary soldier or civilian.

42. Notable examples are the Zongtongfu, or former presidential palace, in Nanjing, which was opened as a museum in 2004, and Chiang's former residence in Xikou, Fenghua County, Zhejiang. 
In his study of China's "new remembering" of the war with Japan, Coble notes the generally "impersonal" nature of officially-sanctioned accounts, and their tendency to treat the conflict as a "numbers game" rather than focusing on the day-to-day experience of the population under Japanese rule. ${ }^{(43)}$ This approach is evident here, for example in a numerical summary of the achievements of the CCP-led guerrilla struggle "behind enemy lines" (di hou zhan chang).Visitors are told that more than 17 million "enemies" were "annihilated" (jian), of whom more than 5 million were "Japanese soldiers." We are not informed of the identity of the remaining 12 million, but presumably many were individuals or communities identified as collaborators with the Japanese and/or opponents of the CCP. The exhibition is entirely silent on the issue of collaboration - discussion of which might invite doubt over the actual extent of Chinese unity or resolution in defying the Japanese aggressors. ${ }^{(44)}$

The fondness for numbers is also highly selective; no casualty figures are provided for the CCP-KMT Civil War that immediately followed victory over Japan, let alone for the later victims of the Great Leap Forward or the Cultural Revolution (which do not rate a mention). Moreover, despite the triumphalist account of the CCP's Civil War victory, the exhibition narrative is vague regarding the deficiencies of KMT governance. Chiang and KMT officialdom are accused of corruption, repressing dissent, favouring the capitalist classes, and economic mismanagement leading to hyperinflation but few details are provided, perhaps for fear of inviting comparisons between the failings of the late-1940s KMT and those of the CCP today. More emphasis is placed on the KMT regime's general duplicity, especially its reliance on American support - without mentioning the far greater extent to which the CCP drew on Soviet backing. The foundation of the PRC can thus be all the more plausibly hailed as the moment at which the Chinese people finally "stood up" and rid themselves of dependence upon, or domination by, foreign powers. ${ }^{(45)}$

Japan hardly features in subsequent sections of the NMC exhibition, except in passing - for example, in a photograph illustrating the normalisation of Sino-Japanese relations in 1972. In the late 1970s (as He Yinan notes elsewhere in this special issue, a particularly warm period in Sino-Japanese relations), Deng Xiaoping hailed Japan as a model for China's reforms ${ }^{(46)}$ - but this goes unacknowledged in the new NMC. Nor is racial or cultural kinship with Japan a discernable theme of the exhibition. Rather, Japan features as the epitome of the foreign oppressor, an image of imperialism on steroids, the significance of whose impact is heightened by the downplaying of the old revolutionary narrative, with its sharper focus on domestic "class enemies." In his 2000 study of paintings from the MCR collection, Kirk Denton proposes a typology encompassing images of "temporal crossings," celebration of "the unity of party and masses," depictions of intellectuals as revolutionary heroes, and "martyrs" to the revolutionary cause. ${ }^{(47)} \mathrm{He}$ also notes that several works of the late 1970s and 1980s, in contrast to those from earlier decades, depicted war as a cause of tragic personal loss more than as the occasion for glorious martyrdom; and that Japanese figures seldom feature in these or earlier paintings. While paintings relating to each of Denton's themes still feature in the NMC, art newly commissioned for the museum's reopening reflects the shift of emphasis away from "revolutionary" concerns. In the new NMC paintings, the Japanese enemy features more prominently - as the agent of China's humiliation, and the object of triumphant Chinese revenge.

Despite the lingering of class-based terminology ("bourgeois," "feudal," etc.), the theme of class struggle is almost entirely absent from the new NMC exhibition. In his analysis of Chinese state museums (established in the 1980s-90s) devoted to the war with Japan, (48) Denton observes a shift away from a conventionally Marxist narrative towards a greater emphasis on "morally unambiguous" depictions of Japanese atrocities that serves "to direct divisive class resentments toward an external other," reinforcing a sense of "national unity and shared national sentiment." In order to highlight "the suffering of the Chinese body" and preserve the memory of past humiliation, several of these museums feature graphic dioramas and images of Japanese brutality. "The emotionality of atrocities," Denton notes, "is one way the state can forge national cohesion without stressing the potentially subversive message of revolutionary class struggle that was until very recently so central to its legitimising myths." However, alongside this newer emphasis on victimhood, the "victor" narrative of the Maoist era still persists, with its greater stress on Chinese strength and agency: on victimhood actively and heroically transcended rather than passively borne.

While the victimhood narrative predominates in the exhibits examined by Denton, he notes that, following its refurbishment in 2005 (the sixtieth anniversary of the end of World War II), the Memorial Hall to the People's War of Resistance against Japan at Lugouqiao has taken "the Great Victory" as its theme, downplaying atrocity and placing "a new emphasis on the war as a key part of the larger global anti-fascist struggle." In its former MCR incarnation, the NMC's modern history exhibit emphasised the ultimate victory of people and party rather than dwelling on the theme of victimhood. The new exhibit highlights the extent of Japanese atrocities - but does not deploy the sort of "horror show" dioramas on display in the Nanjing Massacre Memorial or the museum at Lugouqiao. This may in part be due to the status of the NMC as the supreme embodiment of the official, party-sanctioned view of the national past: while other mainland museums, like their overseas counterparts, increasingly seek to entertain (which, on one level, is what voyeuristic depictions of atrocity do), here the institution's instructional role is approached with greater solemnity. At the same time, the focus on moral as well as military victory over Japan, encapsulated best in the painting "9 a.m., 9 September 1945," underlines the status of the Sino-Japanese conflict as one phase - albeit a crucial one - in the triumphant Communist-led project of constructing a strong, confident, modern Chinese state. With this broader theme to the fore, the NMC thus represents Japanese aggression as a daunting obstacle defiantly swept aside, rather than as a source of lasting national trauma awaiting the therapy of apology and reparation.

Before moving on to examine representations of Japan in the NMTH, it will be useful to note how Taiwanese history, and Japan's role in it, is portrayed in the NMC. Occasional references to pre-1945 Taiwan come in the context of the narrative of Japan's sustained assault on the Chinese state

43. Parks M. Coble, "China's 'New Remembering' of the Anti-Japanese War of Resistance, 1937-1945," art. cit.

44. China is, of course, far from alone amongst formerly occupied countries in terms of the sensitivities surrounding the issue of collaboration. Tony Judt, in Postwar: A History of Europe since 1945, The Penguin Press, 2006, discusses the experience of postwar France, amongst others.

45. It is worth noting, as Parks Coble does (citing Hans Van de Ven), that "it is as right to say that the War of Resistance unmade China as that it made China" (op. cit., p. 410) - by decimating almost the entire economic infrastructure, including trade, local and regional marketing networks, flourishing urban centres, and the supply of money and credit.

46. See Ezra Vogel, Deng Xiaoping and the Rise of Modern China, Cambridge, MA, Harvard University Press, 2011, Chapter 10.

47. Kirk Denton, "Visual Memory and the Construction of a Revolutionary Past: Paintings from the Museum of the Chinese Revolution," in Modern Chinese Literature and Culture, Fall 2000, pp. 203235.

48. See Kirk Denton, "Heroic Resistance and Victims of Atrocity: Negotiating the Memory of Japanese Imperialism in Chinese Museums," art. cit. 
and people. A photograph shows aborigines (described as "minorities," or shaoshu minzu) resisting the initial Japanese occupation, and later another photograph of a school classroom illustrates colonial attempts to "Japanise" the local population. However, subsequent allusions to Taiwan imply that such attempts were uniformly unsuccessful in diluting patriotic ardour for the Chinese motherland. Photographs show "Taiwan compatriots" (along with their counterparts from Hong Kong and Macau) volunteering to fight against Japan, without mentioning that far more Taiwanese actually fought for the imperial army than against it. ${ }^{(49)} \mathrm{A}$ pair of photographs also shows Taiwanese celebrating their reunification with China in 1945. However, no coverage is provided of the KMT's governance of Taiwan (or indeed any aspect of the island's internal affairs) after 1945, nor, therefore, of how or why KMT rule contributed to provoking antipathy towards China and nostalgia for the colonial period amongst many Taiwanese. Instead, the section dealing with the 1980s recounts how "mainlanders" exiled on Taiwan took advantage of the thawing of cross-Straits relations to visit the long-lost motherland, displaying a shirt worn by an ageing returnee with the logo xiang jia ("longing for home"). Finally, a photograph of a recent visit to the mainland by Lien Chan (KMT honorary chairman) gives the impression that Taiwan is being peaceably drawn back into the motherland's embrace.

\section{Japan in the National Museum of Taiwan History}

It was ironically under the premiership of none other than Lien Chan that the first officially-sponsored exhibition on Taiwan's history was organised in 1992. ${ }^{(50)}$ At this time, the official KMT narrative of the national past was similar in many respects to the current CCP account (as enshrined in the NMC). Not only school textbooks, but also public monuments such as the vast Chiang Kai-shek Memorial Hall in Central Taipei, conveyed a vision of the KMT regime as China's bulwark against foreign - especially Japanese invaders and "bandit" Communists alike, eagerly anticipating the day when the "base for recovery of the mainland" would fulfil its function. (51)

Already by the early 1990s, the ground was shifting beneath this static official view of Taiwan's identity; in popular culture, academic historiography and the democratising political scene, a "nativist" (bentuhua) discourse featuring a more benign view of Japan was rapidly gaining ground. Meanwhile, the passing of the "mainlander" (waishengren) elite that had governed the island since the 1940s was accompanied by a steady blurring of the waisheng/bentu divide, as many of "mainland" heritage came increasingly to identify with Taiwan. It was against this background of demographic, cultural, and political change that the decision was taken in 1992 (the year of the first official exhibition on Taiwan's history) to establish the NMTH. It was not until 1998 that a preparatory committee was formed to execute this mandate, the same year witnessing the publication of the very first junior secondary course on Taiwan - Renshi Taiwan (Understanding Taiwan). The Renshi Taiwan textbooks, especially the Society volume (edited by Tu Cheng-sheng, later Education Minister in the proindependence administration of President Chen Shui-bian), encouraged a view of Japan's role in the island's past as one element, alongside China, in the fashioning of a "multicultural" Taiwanese identity. ${ }^{(52)}$

1998 also witnessed the reopening, after extensive refurbishment, of the National Taiwan Museum (NTM - not to be confused with the NMTH), Taiwan's oldest museum, established by the Japanese colonial administration in 1909. As Taiwanese scholars were increasingly inclined to point out, it was the Japanese who had pioneered the academic study of the island's in- digenous cultures, and the exhibiting of their art, culture, and anthropology within Taiwan and overseas. ${ }^{(53)}$ The NTM, an imposing neoclassical edifice, stood testament to a vision of the museum as an instrument of the state for the "civilising" and socialising of the populace - a vision embraced both by colonial Japan (which learnt it from the nineteenth-century West) (54) and by Leninist party-states everywhere. While strong, centralised, bureaucratic control of museums was as much a feature of the KMT state as of its mainland CCP counterpart, in the context of post-Martial Law democratisation, the involvement of civil society actors in Taiwan's museums sector has become increasingly significant. For example, one of the first attempts to protect and celebrate the island's Japanese heritage was an initiative launched in the mid-1990s by a group of local activists to conserve the colonial-era Peitou Hot Springs resort in the suburbs of Taipei - leading to the establishment of the Peitou Hot Springs Museum. ${ }^{(55)}$ Taipei's 228 Peace Memorial Museum, commemorating victims of the "White Terror" during the early period of KMT rule, was a far more politically-charged project arising out of a campaign involving the victims' families; electoral politics meant that not only pro-independence activists but also KMT leaders felt obliged to accommodate their demands. In other cases, such as Tainan's National Museum of Taiwan Literature, the preservation of Japanese architectural heritage has gone hand-in-hand with moves - involving both official and nonofficial actors - to institutionalise a narrative of Taiwanese nation making.

Like the Literature Museum, the NMTH is located in the south-western city of Tainan, the island's main urban centre prior to the twentieth century, and a political stronghold of the pro-independence Democratic Progressive Party (DPP). A figure deeply involved in the establishment of both museums is the prominent historian Wu Mi-cha, who served as deputy head of the Council for Cultural Affairs in the first Chen Shui-bian administration (20002004), and then as director of the NMTH from 2006-2008. Whereas many within the local museum field prefer to portray the business of managing and curating museums as a scientific enterprise conducted by coolly apolitical professionals, ${ }^{(56)}$ Wu has openly acknowledged the political nature of the NMTH project. Among the major models or precedents he cites are historical museums in other "post-colonial" societies - especially Hong Kong, Singapore, and Australia. He sees these societies, like Taiwan, as places where settler populations have been "nativised" (bentuhua), coming to identify primarily with their new homeland. In these societies (in contrast to many

49. Kirk Denton ("Heroic Resistance and Victims of Atrocity: Negotiating the Memory of Japanese Imperialism in Chinese Museums," art. cit.) notes that in autumn 2005, the NMC staged a large exhibition on the "Anti-Japanese Resistance Struggle of Our Taiwan Compatriots" (Taiwan tongbao kangri douzheng zhanlan); he also observes that the resistance of Taiwan's people to Japanese rule was given more prominence in the War of Resistance Memorial Hall (at Lugouqiao outside Beijing) after the exhibition's renovation in 2005.

50. This was held in the Taiwan Provincial Museum in Taipei (now the National Taiwan Museum).

51. See Edward Vickers, "Frontiers of Memory," in Sheila Miyoshi Jager and Rana Mitter (eds), Ruptured Histories: War, Memory and the Post-Cold War in Asia, Harvard University Press, 2007, pp. 209232.

52. See Stéphane Corcuff, "History Textbooks, Identity Politics and Ethnic Introspection in Taiwan:The June 1997 Knowing Taiwan textbooks controversy and the questions it raised on the various approaches to 'Han' identity," in Edward Vickers and Alisa Jones (ed), History Education and National Identity in East Asia, Routledge, 2005, pp. 133-169.

53. See Shao-li Lu, Zhanshi Taiwan: quanli, kongjian yu zhimin tongzhi de xingxiang biaoshu, op. cit

54. Alice Tseng, The Imperial Museums of Meiji Japan, Seattle, University of Washington Press, 2008.

55. LiYa-ling, Jieya hou Taiwan minjian shetuan de fazhan yu shechu wenhua zhongjian: jian yi Taibei shi batouli renxiehui wei lie (The development of civil society groups and local cultural preservation in post-Martial Law Taiwan: A case study of the Taipei Batouli Benevolent Association), National Taiwan Normal University, MA dissertation, 2005

56. See Edward Vickers, "History, Identity and the Politics of Taiwan's Museums: Reflections on the DPP-KMT Transition," art. cit. 
other former colonies), it is hard to see a clear end to "colonialism," since the colonial experience has so radically transformed local demography and culture. Wu expresses particular admiration for the way in which the Australian Museum attempts to address the consequences of this - through embracing a "multicultural" vision of society encompassing indigenous peoples and settler descendants of varying origins. ${ }^{(57)}$

Wu resigned as NMTH Director following the KMT election victory of 2008 - a reflection of the still politically charged nature of the public museums sector. The remit of the NMTH is certainly one with which conservatives within the KMT remain deeply uncomfortable. However, abandoning the project would have been neither financially defensible nor politically expedient. Indeed, President Ma Ying-jeou, ever since his days as Taipei mayor in the late 1990s, has sought to tread a middle path between Chinese nationalism and Taiwanese nativism, recognising the seismic shift that has occurred in the island's political and cultural centre of gravity. By the same token, Wu claims that the NMTH, by virtue of its publicly-funded status, has had to eschew an overtly party-political position, presenting instead a consensual view of the island's past as a basis for further public discussion. ${ }^{(58)}$ However, avoiding controversy is especially difficult for a historical museum focusing on Taiwan, given the insistence of many Chinese nationalists (of the KMT or CCP variety) that "Taiwan" is not a legitimate historical subject in its own right. (59)

Before returning to the question of how successfully the museum achieves this - particularly with respect to its depiction of Japan - it is important to note how the NMTH presents history to the visitor. The NMC makes only limited use of diorama and video, and this still serves an overtly propagandist purpose. The NMTH makes far more lavish and sophisticated use of diorama, aiming to provide visitors with a "realistic" walk-through "experience" of the past, supplemented by various video and audio displays as well as conventional textual exposition. Here it is possible to detect the influence of precedents such as the Hong Kong Museum of History and the "Singapore Story" exhibition of the Museum of Asian Civilisations. ${ }^{(60)}$ The adoption of this exhibitionary approach reflects shifts in museological circles within Taiwan over the past 20 years, as well as the growing cosmopolitanism of the academic community. However, it also reflects how a well-educated population and a context of vibrant popular democracy make it harder for museums to maintain a blatantly didactic posture. As with the NMC, the setting of the museum is also significant; in contrast to the latter's neoclassical austerity and politically central location, the NMTH is an ultra-modernist structure on the outskirts of Tainan, surrounded by extensive landscaped grounds. Through its architecture and surroundings, as well as in the vision of history it explicitly conveys, it thus both celebrates the ultramodern nature of Taiwan's contemporary economy and society, and symbolically embeds its narrative in the island's topography and environment. ${ }^{(61)}$

"Our land, our people: The story of Taiwan" (situ, simin, Taiwan de gushi) is the title of the NMTH permanent exhibition, underlining a self-consciously democratic vision; the focus here is not, as in the NMC, on heroic figures or "great leaders." The exhibition is very text-heavy, but eschews a stridently ideological tone. This does not mean that the NMTH is, or even pretends to be, "ideology-free"; it clearly adopts a political mission - that of providing the historical scaffolding for a robust and inclusive sense of Taiwanese identity. It does this through focusing primarily on the development of society rather than on high politics, depicting the changing customs, culture, and daily lives of the island's diverse communities. Episodes of immigration, and of trade with or colonisation by other societies, are highlighted, along with the plural- ism and multiculturalism that have thus come to characterise Taiwan.

This bottom-up perspective also has the advantage, from an official standpoint, of minimising the potential for provoking political controversy though there is no indication that this was a prime consideration in the decision to focus on social history. However, concerns to minimise controversy, not least with regard to coverage of the Japanese colonial period, caused the exhibition's designers to engage in a pre-emptive "rectification of terms." Thus the expressions rizhi ("Japanese rule") or riju ("Japanese occupation") were avoided, since the choice of one or the other might have been taken to imply recognition or otherwise of the legality of the colonial administration. Instead, the neutral term shidai ("period") was used in relation to every era - not just the Riben shidai ("Japanese period"), but also those of the Dutch, the Zheng clan, the Qing dynasty, and the KMT.

A related issue was the choice of a system of dating, since Taiwan, like Japan (but unlike the PRC), still uses the traditional practice of dating by reign. To have used this system would have involved taking a definite position over which state had jurisdiction over Taiwan at any particular time, whereas the use of the Western calendar allows this issue to be fudged; the latter was therefore chosen.

The exhibition is divided chronologically into six periods, each with a thematic title:

1. "The early residents" (zao qi de ju min)

2. "Encounter between disparate cultures" (yi wenhua xiang yu)

3. "Chinese migration to Taiwan" (Tangshan guo Taiwan)

4. "Territorial societies and plural cultures" (diyu shehui yu duoyuan wenhua)

5. "Transformations and the New Order" (ju bian yu xin zhixu)

6. "Towards a diverse, democratic society" (maixiang duoyuan minzhu shehui)

The section on the Japanese period occupies the central area, taking up the largest proportion of floor space - and of pages in the exhibition catalogue. ${ }^{(62)}$

The first two sections of the exhibition respectively establish the diverse but largely Polynesian/Pacific (i.e. non-Chinese) nature of Taiwan's prehistoric cultures and peoples, and the plurality of the influences shaping Taiwanese society as it entered the historical record. Japan is described as "coveting" Taiwan as early as the late sixteenth century - perhaps a comment both on Japanese avarice and on the inherent desirability of the Itha Formosa. Here the exhibition features a circular diorama depicting three groups of "foreigners" (wailaizhe) encountering the island's indigenous peo-

57. Wu Mi-cha, Jianli yi zuo guojia lishi bowuguan ("Constructing a Museum of National History"), in Frank Muyard, Liang-Kai Chou, and Serge Dreyer (eds), Objects, Heritage and Cultural Identity, Nantou, Taiwan Historica, 2009, pp. 285-292.

58. In addition to Wu's 2009 paper, references to his views here and below are derived from a talk he delivered on "Japan in the NMTH" at the University of Tsukuba, Japan, on 20 February 2013.

59. Ilaria Maria Sala describes how this issue of what is, or is not, a legitimate historical "unit" was a controversy that dogged the establishment of new history museums in Hong Kong and Macau during the late 1990s: "Bringing History Up to Date:The New Museums of Macau and Hong Kong," China Perspectives, No. 22, 1999

60. Wu also cites the example of the Edo Tokyo Museum. These museums have in turn been influenced by recent changes in exhibitionary practice in the West.

61. For an extensive discussion of the role of public space in the construction of identity in contemporary Taiwan, see Joseph R. Allen, Taipei: City of Displacements, University of Washington Press, 2012.

62. Situ, simin, Taiwan de gushi ("Our land, our people: Taiwan's story"), exhibition handbook, NMTH, 2012. Eighteen pages of the handbook are devoted to the Japanese period, while other sections rate between eight and fourteen pages apiece. 


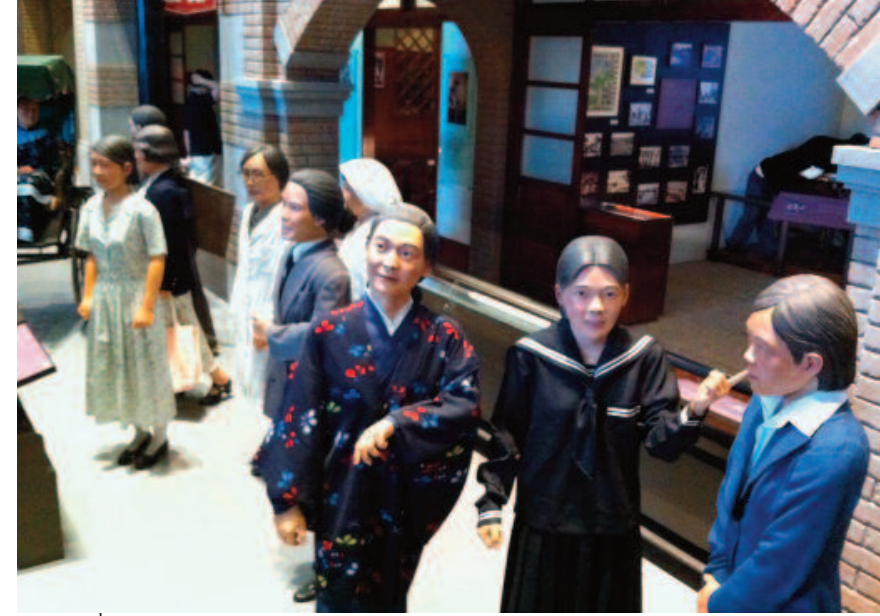

Photo 3 - Diorama of Taiwanese women in the section on "[the] new era and the new woman." (Photograph by the author)

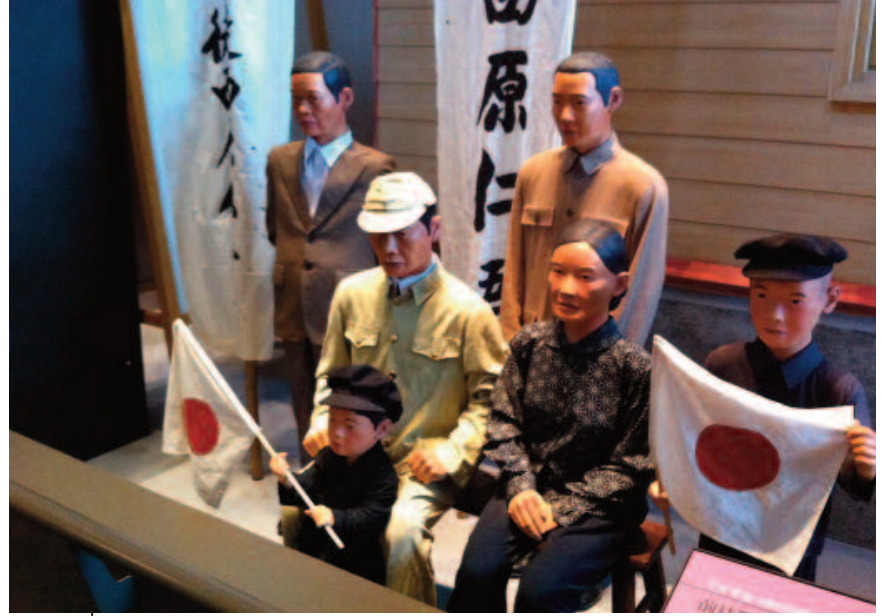

Photo 4 - Diorama of a Taiwanese family bidding farewell to a son leaving for service in the Japanese imperial army. (Photograph by the author) ples during the sixteenth-seventeenth centuries: Christian Westerners, Han Chinese, and the Japanese. The advent of Chinese settlement is the subject of the next two sections. "Territorial societies and plural cultures," focusing on the period of Qing rule (late seventeenth to late nineteenth centuries), depicts Taiwan as a frontier society of settler communities and aboriginal tribes bound by their respective customary and religious practices; there is much material here on festivals and ritual. The overarching theme, as described by Wu, ${ }^{(63)}$ is "community" - underlining Taiwan's status as a society on the fringes of the Qing Empire, left largely to its own devices.

In the section on the era of Japanese rule, however, the exhibition has far more to say on issues of government and administration, reflecting a perception of this as the key period for modern state formation on Taiwan. This view is starkly at odds with the old KMT-sponsored orthodoxy; school history textbooks until the 1990s located the island's developmental take-off very firmly in the post- 1945 period of KMT rule, with some acknowledgement of late nineteenth-century Qing efforts at modernisation. ${ }^{(64)}$ By contrast, the section of the NMTH dealing with the post-war period of KMT rule takes as its main theme the fraught but ultimately successful struggle to democratise Taiwanese society; in other respects - institutional, administrative, educational, industrial, and commercial - the implicit message is that it was the Japanese legacy that made the KMT state viable.

It is for this reason that the section on the Japanese period is entitled "The Great Transformation and the New Order" (though "Great" is omitted from the English translation). The tone throughout is notably free of anti-Japanese rhetoric; although the exhibition goes on to describe the (heroic but doomed) Taiwanese resistance to the Japanese occupation, the panel discussing the island's "cession" explains that Japan engaged in territorial expansion so as to "free itself of the dominance of European and American imperialism and safeguard its national security and interests." (65) Having established control, the Japanese are described as governing "on the basis of modern reason and scientific principles" (jindai lixing yu kexue yuanli). The application of reason and science is then highlighted with respect to dealings with the "indigenes," whose cultures were subjected to intensive study by Japanese anthropologists (many of them associated with the museum later to become the NTM, and with the Imperial University in Taipei). This project was conducted in tandem with efforts to control and "civilise" these aboriginal tribes.

The modern technologies of control that the Japanese colonial state brought to Taiwan are a particular focus of this section. These include "precise surveys and scientific administration" (jingmi diaocha yu kexue zhili), notably the first thorough censuses and cadastral surveys conducted on the island. However, the most prominent feature of the entire colonial-era exhibit is a reconstruction of a local police post (paichusuo). While the baojia (household registration) system is depicted as giving the police wide powers to interfere in the lives of ordinary people, they are not portrayed simply as the remorseless agents of colonial oppression; other roles listed include "prevention of infectious diseases, promotion of agricultural technology, mobilizing people to clean and tidy up [the local area], and organising the collecting of taxes." The importance of securing the collaboration of local elites is also noted, underlining the complicity of the local population in the colonial enterprise. Here visitors can watch a video of interviews with elderly people recalling their experiences of life under Japanese administration, including one with a Taiwanese former police officer. ${ }^{(66)}$

In Taiwan as in Japan itself, a principal instrument of modern state formation was schooling, which the section on "New Education and Modern Culture" describes the colonisers as using both to mobilise "human capital" and to socialise the local population as loyal imperial subjects; the display here features a small reconstructed classroom and contemporary textbooks. Both at school and through their experience of modern consumerism, the island's inhabitants encountered a distinctively Japanese variant of modernity. The Japan-influenced Westernisation of local lifestyles is illustrated with a mockup of a Taipei shopping street of the inter-war period - comprising a café, a record shop, and a cinema. The liberating effect of this cultural transformation on women is particularly emphasised, with a diorama showing female figures in various roles - nurse, teacher, student, office lady - now open to them: "new era and the new woman" (xin shidai yu xin nuxing). But one of the unintended effects of the introduction of modern education was to

63. Wu Mi-cha, Jianli yi zuo guojia lishi bowuguan, op. cit.

64. Economic and commercial developments in late-Qing Taiwan are also given considerable coverage in the NMTH exhibition.

65. The reference to Western imperialism is omitted from the English translation. This is reminiscent of the arguments employed by right-wing Japanese to justify the country's twentieth-century wars of aggression.

66. Wu Mi-cha reported in his February 2013 talk at Tsukuba University that the most popular place in the museum for taking photos was the diorama of Japanese policemen lined up outside the paichusuo; indeed, this diorama seems to have been designed for this very purpose. 
stimulate demands amongst a new educated elite for greater civil rights, and the 1920s movement for a "Taiwan council" - prefiguring post-war calls for democratisation - is given extensive treatment here. The exhibition thus identifies the contribution of the Japanese period not only to the island's "modernisation," but also, and especially, to engendering a specifically "Taiwanese" political consciousness - thus providing the foundation for the articulation of Taiwanese identity in the post-Martial Law era.

Also pursuing the theme of modernisation, a subsection records the commercialisation of the agricultural sector, as well as the development of industry and infrastructure more generally. The creation of the Sun Moon Lake Hydro-electric Project is discussed here; the resulting lake has become a scenic feature of the local landscape celebrated in official literature on the Chinese mainland as well as in Taiwan. However, while in the PRC (as under the Martial Law-era KMT) the Japanese origins of this lake are generally obscured, here they are cited as one of many contributions by the former colonisers to the island's development.

Like all aspects of Taiwanese society, agriculture and industry are shown as having been profoundly affected by "the time of the flames of war" (fenghuo suiyue). The impact on ordinary people of "dig for victory" efforts and campaigns to boost industrial production (especially in the war's latter stages) is illustrated here, as is the intensified drive to "Japanise" the population - through linguistic measures, the "Japanisation" of names and the introduction of state Shinto. In the aforementioned cinema visitors can also view wartime Japanese propaganda films. However, while the war is depicted as a time of suffering for Taiwan's people, not least due to Allied bombing raids, even here the exhibition does not portray the Japanese as callous oppressors. The fact that huge numbers of Taiwanese volunteered for military service (before the introduction of conscription in 1944) is explicitly acknowledged. Unacknowledged, by contrast, is Japan's use of foreign slave labour in Taiwan during the latter stages of the war, or the experiences of Taiwanese "comfort women" servicing the imperial army.

The abrupt end of Japanese rule in 1945 is not greeted here as a "liberation"; Taiwan is described neither as "returning to" nor "recovered by" China. Rather, the Japanese are simply described as "leaving" and the KMT regime as "coming to" the island. One foreign regime departs and another arrives, both to leave their lasting imprint on Taiwan's cultural palimpsest.

\section{Discussion}

Wu Mi-cha claims that the NMTH represents a "consensus" view of Taiwan's past that wholly satisfies neither the "Blue" conservative "pan-Chinese" nationalists of the KMT, nor their "Green" pro-independence opponents. ${ }^{(67)}$ Some of the latter complain that the exhibition gives insufficient prominence to the post-war KMT "White Terror," while unnecessarily emphasising the Chinese origins of most of Taiwan's people. Meanwhile, some in the Blue camp remain unreconciled to the notion of a "national" museum focusing on Taiwanese, as opposed to Chinese, history, while others object to the positive (zhengmian) portrayal of Japan.

The portrayal of the Japanese and of other past foreign presences does not harp on the theme of Taiwanese "victimhood" or suffering. This contrasts with the narrative put forward in some other museums in Taiwan; the 228 Peace Memorial Museum, for example, certainly emphasises the victimisation of Taiwanese - though at the hands of the post-war KMT regime rather than the Japanese. Indeed, there has been a tendency for "nativist" narratives of the Taiwanese past to retain the essential narrative structure of conven- tional nationalist accounts of modern Chinese history - victimhood and its transcendence - with Taiwan substituted for "China" as the national subject. ${ }^{(68)}$ However, the NMTH supplies a historical narrative that is both more upbeat and more inclusive; besides the indigenous peoples, Chinese, Japanese, Dutch, Spanish, and British have all been enticed by the delights of this island paradise, and have all left their mark. By the same token, while "they" may become part of "us," none of "them" has a prior or exclusive claim; they come and go, but the island belongs to those, of whatever origin, who remain. This seems to be a central message of the exhibition, reflected also on the cover of the handbook, showing Japanese as well as Western figures amongst a gallery of silhouettes from the museum's dioramas.

The NMTH plainly assumes the mission of tracing the story of a distinctively "Taiwanese" subject, just as the NMC presents the story of the "Chinese" people, but of what does this national distinctiveness consist? In the NMC, "the people" are implicitly represented as a homogenous, undifferentiated, unchanging mass; "minorities" from Taiwan to Tibet feature as bit players in a drama centred squarely on a culturally and biologically constant "Han" national subject. It is this national subject in its totality of which the CCP is portrayed as the supreme manifestation, and of whose modernisation it becomes the triumphant champion; class struggle no longer supplies the narrative backbone. The inhabitants of Taiwan fall definitely within the pale of this Han-supremacist subjectivity, and indeed assume a certain eminence by virtue of having fallen to the initial onslaught of Japanese imperialism. The Japanese are starkly and unproblematically "other" in the NMC account, and victimisation at their hands assumes an almost totemic status in the narrative of national "rejuvenation"; meanwhile, any Japanese contribution to China's modernisation, or that of Taiwan, goes entirely unacknowledged. In the NMTH, by contrast, Taiwan's modern development and the very emergence of a modern Taiwanese subjectivity are represented as crucial legacies of Japanese rule. Moreover, that subjectivity itself, in rejecting Taiwan's incorporation within a singular, homogenous conception of (Han) Chinese nationhood, embraces the Japanese contribution to a cultural diversity portrayed as the defining feature of "Taiwaneseness."

While visitors or settlers from overseas are thus implicitly included in the NMTH definition of "our people" (simin), the definition of "our land" (situ) is far more circumscribed: the exhibition deals almost exclusively with events that take place on the island of Taiwan. With respect to the portrayal of Japan, this has two notable consequences. Firstly, it means that, while the effects of the Second World War on Taiwan are much discussed, questions of what was done by or to Taiwanese people in other theatres of war - China, South-East Asia, or the Pacific - are not addressed. ${ }^{(69)}$ It also means that the wartime experiences of Taiwan's mid-century immigrants from the Chinese mainland are hardly acknowledged, despite the profound implications that their very different memories of the Japanese were to have for inter-communal relations on the island. The savagery of the Sino-Japanese conflict, to the fore in Beijing's NMC, is wholly absent from the NMTH narrative, but is nonetheless part of the history and memories of many of today's Taiwanese. Meanwhile, intent on portraying the entire Chinese nation ("Taiwan compatriots" included) welded into a "Flesh and Blood Great Wall" to resist the Japanese invasion, the NMC ignores the fact that many

67. This refers to Wu's Tsukuba University talk, 20 February 2013.

68. For more on this, see Edward Vickers, "Rewriting Museums in Taiwan," art. cit.

69. In this respect, the approach of the NMTH - focusing on the suffering experienced by us, rather than that which we inflicted on others - can be compared with that of most Japanese museums when it comes to the coverage of the war. 
possessing Chinese "blood" were less than wholly committed to this struggle. Both the NMC and NMTH accounts thus play down the history of division and conflict within their respective societies.

In other respects, the two museums differ starkly, both in their depictions of Japan and the Japanese, and in their underlying conceptions of their public function. The extent to which these divergent portrayals are due to the very different ways in which Japan affected Taiwan and the Chinese mainland during the first half of the twentieth century should not be forgotten; the War of Resistance was simply far more traumatic, for far more people, than Taiwan's experience of colonialism. Indeed, it cannot be emphasised enough that the anti-Japanese sentiment that the NMC reflects (and arguably stokes) is not something that the CCP has simply manufactured out of thin air for its own nefarious purposes - the impression typically relayed by Japan's mass media. Any propaganda campaign, to be successful, must appeal to the lived reality or folk memory of its target population, as the failure of the KMT's decadeslong campaign to transform Taiwanese into ardent Chinese patriots amply demonstrates. For this reason, the NMC narrative of modern Chinese history should be seen not just as a crude attempt at patriotic "brainwashing," but also as part of the CCP's bid for the support of a large domestic constituency amongst whom anti-Japan messages strike a chord.

Nonetheless, even where there is a strong argument to be made for depicting Japan's impact on China as constructive rather than destructive for example, in the context of the late Qing reforms and the Japanese influence on China's nationalists - the NMC avoids complicating its portrayal of Japan as unremittingly alien and hostile. This reflects the rigid and essentially ethnic definition of nationhood that it implicitly espouses; at various points not only "Taiwan, Hong Kong, and Macau compatriots" are depicted as rallying to the national cause, but "overseas Chinese" as well. Ethnic minorities feature little in the NMC story, while "foreign friends" of the CCP (generally Westerners) remain definitively beyond the national pale. Neither ethnic nor cultural kinship with Japanese "devils" is acknowledged. In this respect, the NMTH takes almost the opposite approach, although its insistent emphasis on the plural origins of Taiwan's people and culture perhaps acknowledges the continuing power of ancestry as an argument for identity, in this case as a means of countering the totalising biological and cultural determinism of the "One China" camp. ${ }^{(70)}$

Nonetheless, the image of Taiwan as an open, plural society is not simply a manufactured one, and one need look no further than the museums sector for evidence of this. While the NMTH portrays Taiwanese society as "multicultural," focusing on the lives of ordinary people (relying for this purpose largely on artefacts donated by the general public), other institutions - public and private - promote very different messages concerning the island's culture and identity. Taipei's massive Chiang Kai-shek and Sun Yat-sen Memorials still stand as monuments to the ideology of Chinese nationalism. ${ }^{(71)}$ Meanwhile, the National Palace Museum continues to enshrine the elite high culture of imperial China, and to embrace a vision of Taiwan and its Chinese motherland united by this shared cultural legacy - even if the audience for this consists increasingly of visitors from the mainland bussed in on package tours. During the period of DPP rule (2000-2008), the government attempted to promote its nativist Taiwanese vision of national identity through these institutions too, much as the KMT had previously attempted to impose its own orthodoxy through the state apparatus. However, the capacity of the state - whether DPP- or KMT-led - to impose a singular, normative vision of national identity through official cultural institutions has been significantly undermined by the practice of democracy and the power of an open media. The very fact that the NMTH opened under a KMT administration that was simultaneously pursuing cultural detente with Beijing is testament to the now-entrenched diversity of Taiwan's cultural landscape. ${ }^{(72)}$

Museums in mainland China are by no means uniform in their coverage of the past in general, or Sino-Japanese relations in particular; and diversity in perspective or interpretation is nowadays more than matched by variety in presentational mode. Nonetheless, they remain transmission belts for party ideology - "bases for patriotic education" - devoted to the chronological narration of a drama starring an essentially unchanging subject: the Chinese (i.e. Han) people. This is especially the case in the NMC, which retains the old narrative of a messianic party delivering liberation from oppression, even while foreign imperialism, epitomised by Japan, has replaced the old "feudal classes" as oppressor-in-chief. But while the NMC invokes the themes of national humiliation and victimhood, it does so in less graphic terms than many of the atrocity-centred museums established in the $1980 \mathrm{~s}$ and 1990s; instead, it stresses the transcendence of victimhood in the triumphant pursuit of national liberation, unity, and modernisation.

In the NMTH, as in other Taiwanese museums, a conventional chronological narrative is also adopted, and a clear ideological message is discernible. However, the story here is not one of deliverance from above for a chosen people, but of a diverse community constructing a prosperous and democratic future out of a plethora of historical ingredients - including a hefty contribution from Japan. Whereas in the NMC "the people" are a rhetorical abstraction, or an amorphous mass (epitomised by sculptures of anonymous figures emerging out of a single block) to be shaped and led by the CCP, in the NMTH they are the stars of the show, the authors of their own destiny.

The emphasis on national humiliation and victimhood that has long characterised much identity discourse in the "two Chinas" has thus been at least partially transcended in the new NMC and NMTH. Rather than wallowing in past suffering, both exhibits celebrate the forward thrust of history and the promise of national progress. However, the way in which this transcendence is presented, and its significance interpreted, differs hugely in each case. The NMC celebrates victory over a barbaric foe - the Japanese - whose barbarism underlines the moral superiority of a united Chinese nation determinedly pursuing its own distinct form of modernity. The NMTH, by contrast, represents a history of conquest and colonisation - with the Japanese as its most enlightened or "scientific" exponents - transcended not through defiant resistance, but through incorporating various "others" into a selfconsciously hybrid "Taiwanese" identity. It thus displays not only a different approach to the Japanese legacy, but a different conceptualisation of national identity itself - one that in embracing multiple antecedents puts distance between the "Taiwanese" self and a singular, monolithic "China."

\section{Edward Vickers is Associate Professor in Comparative education at the Department of education of Kyushu University. Kyushu University, 6-19-1 Hakozaki, Higashi-ku, Fukuoka 812-8581, Japan (vickers.edward.645@m.kyushu-u.ac.jp).}

70. For more on the continuities in identity discourse in post-Martial Law Taiwan, see Melissa Brown, Is Taiwan Chinese?, University of California Press, 2004.

71. The National Military Museum in Taipei - a KMT-affiliated institution - presents a more Sinocentric account of past conflicts with Japan, placing considerable emphasis on the resistance of Taiwan's people to Japanese rule (according to Denton, "Heroic Resistance and Victims of Atrocity: Negotiating the Memory of Japanese Imperialism in Chinese Museums," art. cit.), in contrast to the 228 Museum in Taipei, or the NMTH.

72. For more on this see Edward Vickers, "Rewriting Museums in Taiwan," art. cit. 